\title{
Two new records of cheilostome Bryozoa from British waters
}

\author{
BRYAN WASSON ${ }^{1}$ AND HANS DE BLAUWE ${ }^{2}$ \\ ${ }^{1}$ Marine Ecological Surveys Ltd, 3 Palace Yard Mews, Bath, BA1 2NH, ${ }^{2}$ Scientific Collaborator, Department of Invertebrates, Royal \\ Belgian Institute of Natural Sciences, Vautierstraat 29, B-1000 Brussels, Belgium
}

The recently described Escharoides bishopi and the non-native Fenestrulina delicia are recorded for the first time from British waters.

Keywords: Fenestrulina delicia, Fenestrulina malusii, Escharoides bishopi, non-native, cheilostome, new record

Submitted 5 April 2014; accepted 23 September 2014

\section{INTRDDUCTIDN}

In 2013, Marine Ecological Surveys Limited (MESL) was commissioned by Lafarge Tarmac Marine Ltd and Van Oord UK Ltd to perform the year four benthic and geophysical monitoring surveys of Area 481, Inner Dowsing, for the purposes of aggregate extraction licensing. Area 481 is located approximately $20 \mathrm{~km}$ offshore from Skegness on the Lincolnshire coast, and covers an area of roughly $8 \mathrm{~km}^{2}$.

During the laboratory macrofaunal analysis, two species of encrusting cheilostome Bryozoa were identified that had not previously been recorded in the United Kingdom. Escharoides bishopi De Blauwe, 2006 was originally described from small colonies on the inner surface of shells of Cerastoderma edule (Linnaeus, 1758) from the Kwintebank, a highly dynamic sandbank in the western Belgian part of the North Sea (De Blauwe, 2006). Fenestrulina delicia Winston, Hayward \& Craig 2000, was described from specimens collected in New England (Winston et al., 2000). Previously the life history of the species had been studied in specimens from the same area by Craig (1994). It was referred to only as genus but the photographs show that this is the first appearance of $F$. delicia in a publication. Fenestrulina delicia has recently made a dramatic appearance in European mainland waters. Specimens have previously been collected along the European coast from Brittany in France all the way to Germany (De Blauwe et al., 2014). Prior to this publication the first confirmed European record was from The Netherlands in 2005 (De Blauwe, 2008).

\section{MATERIALS AND METHDDS}

The seabed was sampled using a mini Hamon grab and the samples were preserved in $4 \%$ formaldehyde solution in seawater. The samples were later transferred to $70 \%$ industrial methylated spirits for laboratory processing. During

Corresponding author:

B. Wasson

Email: bryan.wasson@mesltd.co processing all encrusting Bryozoa were allowed to air dry. Several other commercial laboratories were contacted in an attempt to gather more specimens of Fenestrulina collected from British waters.

\section{RESULTS}

A single colony of Escharoides bishopi was discovered and Fenestrulina delicia was identified in eight samples. After identification, the sole colony of E. bishopi and one colony of $F$. delicia were prepared for scanning electron microscopy (SEM). Any remaining ambient moisture was removed from the colonies using a critical point drier before being coated in gold ready for imaging. Fenestrulina specimens were sent from other commercial laboratories. All had been identified as Fenestrulina malusii (Audouin, 1826) but many were actually Fenestrulina delicia.

\section{DISCUSSIDN}

\section{Escharoides bishopi}

The main identification aid for British cheilostome Bryozoa is Hayward \& Ryland (1998). Identification was not possible using this so the newer book on Bryozoa of Belgium and The Netherlands by De Blauwe (2009) was consulted and resulted in a positive identification.

The sole colony discovered in the survey of Area 481 is so far the first and only record of this species in British waters. It is a small spot colony and although quite damaged during collection and subsequent processing it is possible to see that it was made up of about fifteen zooids (Figure 1). The frontal wall is imperforate with large marginal areolae. The original description reports that there are six hollow spines in nonovicellate zooids reducing to two or sometimes four in ovicellate zooids, but it also refers to French material in which most ovicellate zooids show four spines. In this UK colony only one undamaged non-ovicellate zooid remains and it seems to have four spines. All the undamaged ovicellate zooids appear to 


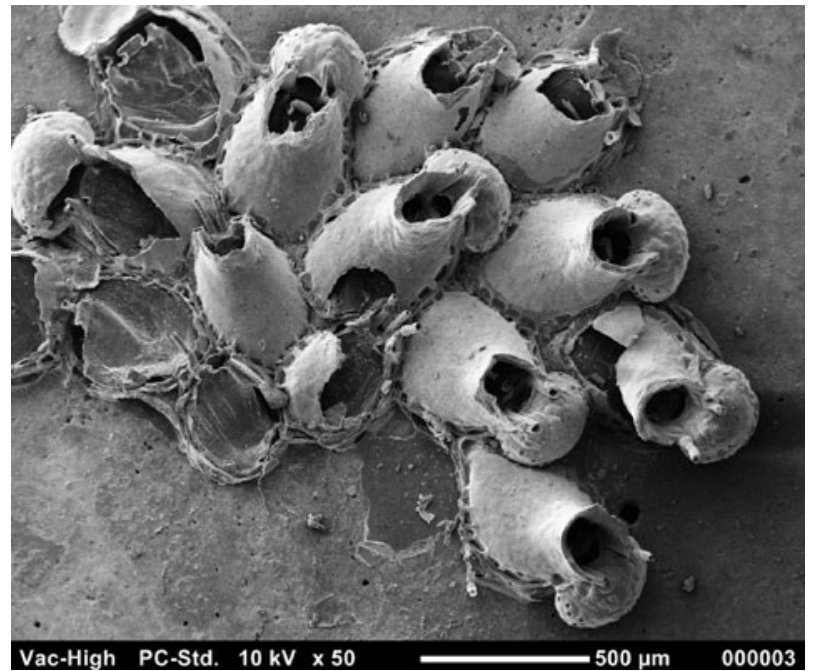

Fig. 1. Escharoides bishopi: whole colony.

have only two. The flared peristome has three denticles on the inner edge with the middle one clearly bifid (Figure 2). There are no avicularia. The ovicell has a broad granular appearance and has scattered pores low on the periphery most easily seen from an oblique angle. The ancestrula has been destroyed. The colony had grown on the inside surface of a portion of a Mytilidae shell.

This specimen of E. bishopi was found in a benthic sample collected on 13 July 2013 at $53^{\circ} 19^{\prime} 0.12^{\prime \prime} \mathrm{N} \mathrm{O}^{\circ} 40^{\prime} 21.87^{\prime \prime} \mathrm{E}$ from a depth of $21.1 \mathrm{~m}$. The seabed at that station was described from the accompanying seabed imagery as coarse sand, some gravelly sand and pebbles with no visible fauna apart from some Spirobranchus tubes. This specimen has been lodged in the Bryozoa collection of the Natural History Museum, London with the registration number: NHMUK 2013.10.28.2.

Escharoides bishopi is rare. Prior to this publication, there have been very few records: five colonies from the Kwintebank, Belgium (De Blauwe, 2006, 2009); twenty colonies on one single shell from Le Val André, Brittany, France (De Blauwe, 2006, 2009); six colonies from the

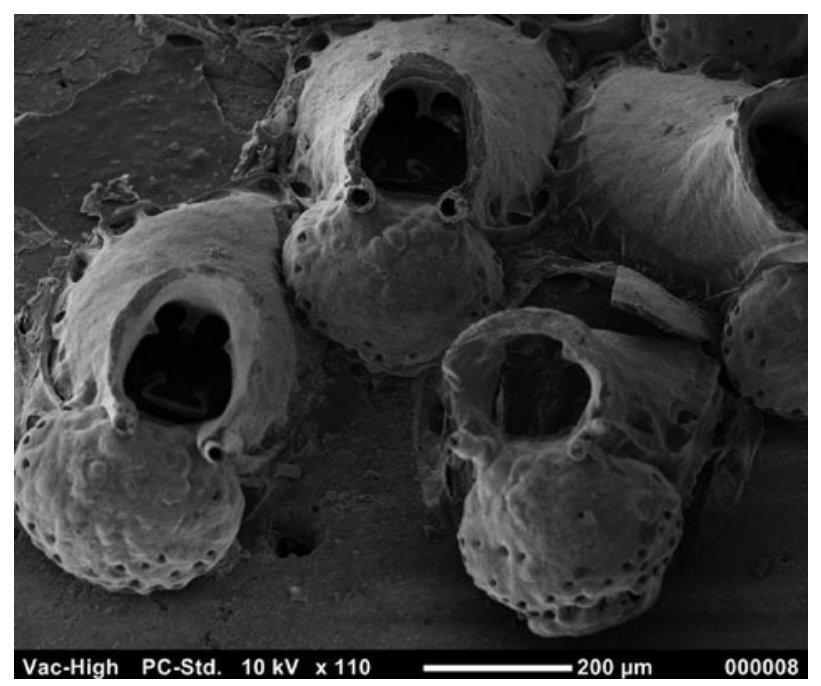

Fig. 2. Escharoides bishopi: close up showing the three denticles on the inner edge of the peristome.
Hinderbank, Belgium, on 20 June 2005 (De Blauwe, 2009) and one colony from Buiten Ratel, Belgium on 5 March 2012 (De Blauwe, 2012). All colonies were found on the inside of shells.

\section{Fenestrulina delicia}

During discussion regarding the discovery of the colony of Escharoides bishopi it was suggested by the second author that Fenestrulina delicia was likely to be present, though as yet unreported, in British waters. The macrofaunal analysis of the Area 481 project had already recorded Fenestrulina malusii from several samples. The next sample analysed had $F$. delicia. By the end of the macrofaunal analysis, and having rechecked all the specimens of $F$. malusii it transpired that all specimens of the genus were actually $F$. delicia. This project had eight samples containing this species.

Fenestrulina delicia is not featured in the standard work for the identification of British Bryozoa, the aforementioned Hayward \& Ryland (1998). The genus is quite distinctive in appearance and the general assumption being that there is only one species from this genus in north-east Atlantic waters has meant that this non-native arrival has gone unnoticed by macrofaunal analysts in the UK until now.

The most striking difference between $F$. delicia and F. malusii is that in F. delicia there is a smooth raised rim of non-perforate calcification around most of the zooid. This rim appears to partly overlap the outermost pores of the frontal surface (Figure 3). Also the ovicell of F. delicia forms coarse radiating ridges in contrast to the almost smooth ovicells in F. malusii (Figure 4).

The specimen of $F$. delicia that was prepared for SEM has also been lodged in the Bryozoa collection of the Natural History Museum, London with the registration number: NHMUK 2013.10.28.1. The sample containing this specimen was located at $53^{\circ} 19^{\prime} 0.12^{\prime \prime} \mathrm{N} \mathrm{O}^{\circ} 40^{\prime} 21.87^{\prime \prime}$ E. It was taken on 13 July 2013 from a depth of $21.1 \mathrm{~m}$ with the sediment type being described as gravelly sand.

The 2013 benthic macrofaunal survey of Area 481 was the third conducted by MESL. It had previously been surveyed in 2008 and 2011. It is standard MESL protocol to keep a reference collection from each survey so there were specimens

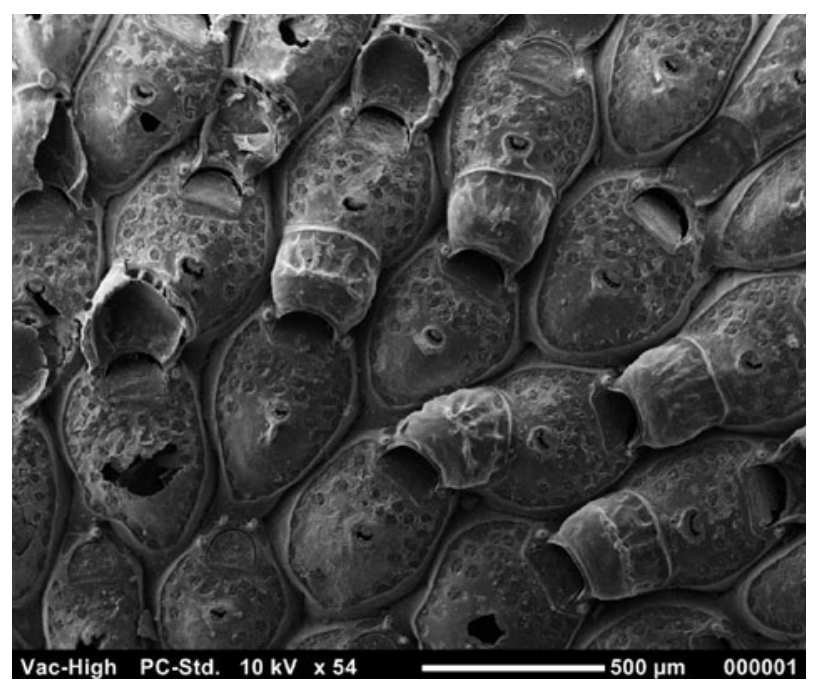

Fig. 3. Fenestrulina delicia. 


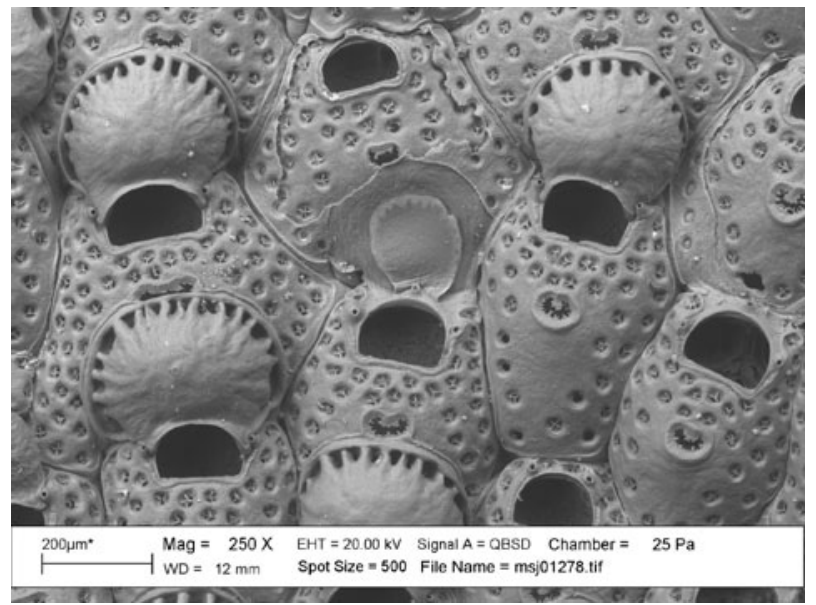

Fig. 4. Fenestrulina malusii (image courtesy of the Natural History Museum, London).

retained from those previous surveys that had been recorded as Fenestrulina malusii. These two specimens from the previous surveys were checked and were actually Fenestrulina delicia. All other referenced specimens recorded as $F$. malusii in the archives of MESL were then checked. Two more specimens of $F$. delicia were found. One collected in 2009 from just offshore the mouth of the Humber a little up the coast from Area 481 and one from Sullom Voe in the Shetlands collected in 2012 .

Of the specimens sent by the Dorset laboratory of APEM Ltd, two were $F$. delicia. Both of these were collected from the Clipper South gas field from the United Kingdom Continental Shelf (UKCS) Area 48/19. One was collected on 28 December 2008 and the other on 28 February 2009. Another specimen of $F$. delicia was confirmed by a photograph sent from Marine Invertebrate Ecological Services (MIES). This example, collected in 2011, was also from the UK southern North Sea gas fields at approximately $53^{\circ} 15^{\prime} \mathrm{o}^{\prime \prime} \mathrm{N} 1^{\circ} 30^{\prime} \mathrm{o}^{\prime \prime} \mathrm{E}$.

Thomson Unicomarine Ltd sent twenty-five specimens all of which had been recorded as F. malusii. Of these, ten were $F$. delicia. Many of these were from a similar area of the southern North Sea as the other loaned specimens though with the notable exceptions of two specimens collected from Carlingford Lough, Northern Ireland, on 30 March 2008, one from Larne Lough, Northern Ireland collected on 1 November 2008 and one from the Firth of Clyde on the west coast of Scotland collected on 23 June 2009. These specimens, along with the MESL specimen from Sullom Voe in the Shetlands, show that $F$. delicia has a verified distribution that includes Ireland, the west coast of Scotland and the most northerly reaches of the UK, so its distribution is not just limited to the English Channel and North Sea.

Amongst the material from Thomson Unicomarine Ltd were several specimens collected earlier than the previously reported earliest confirmed European record. This had been in 2005 from The Netherlands (De Blauwe et al., 2014), but the earliest record is now a specimen collected from the North Sea aggregate Area 408 which is located approximately 60 miles east of the Humber estuary. Two colonies of F. delicia had been growing on the inside of the shell of a Glycymeris glycymeris (Linnaeus, 1758) collected on 30 July 2002. This specimen is part of the faunal collection of Thomson
Unicomarine Ltd and is stored there with the reference code 30960. Two other early specimens had been collected in 2003 from the nearby Race Bank as part of the UK Department of Energy and Climate Change's offshore energy Strategic Environmental Assessment programme. These were both collected on 2 September 2003 from the locations $53^{\circ} 14.4075^{\prime} \mathrm{N} \quad 0^{\circ} 51.4235^{\prime} \mathrm{E}$ and $53^{\circ} 14.9462^{\prime} \mathrm{N}$ $0^{\circ} 52.1908^{\prime} \mathrm{E}$.

Access was granted to all the Fenestrulina specimens held by the Portsmouth laboratory of Fugro EMU Ltd. Once more these were a mixture of $F$. malusii and $F$. delicia. Many of these $F$. delicia specimens were again from a similar area of the British southern North Sea as many of the other commercial laboratory specimens due to a lot of monitoring of industrial activity such as that of aggregate or energy companies. However several of the Fugro EMU Ltd specimens were from new locations such as two specimens from the English Channel (2005 and 2013) and one from the mouth of the River Thames (2010) thus further enriching the known distribution.

Figure 5 shows some of the locations of specimens of $F$. delicia discovered during this study. Several locations had many duplicate specimens due to high sampling activity over many years so if this was the case then only the earliest record is shown. It is clearly the case that F. delicia has a very widespread distribution and has been in the UK for some time.

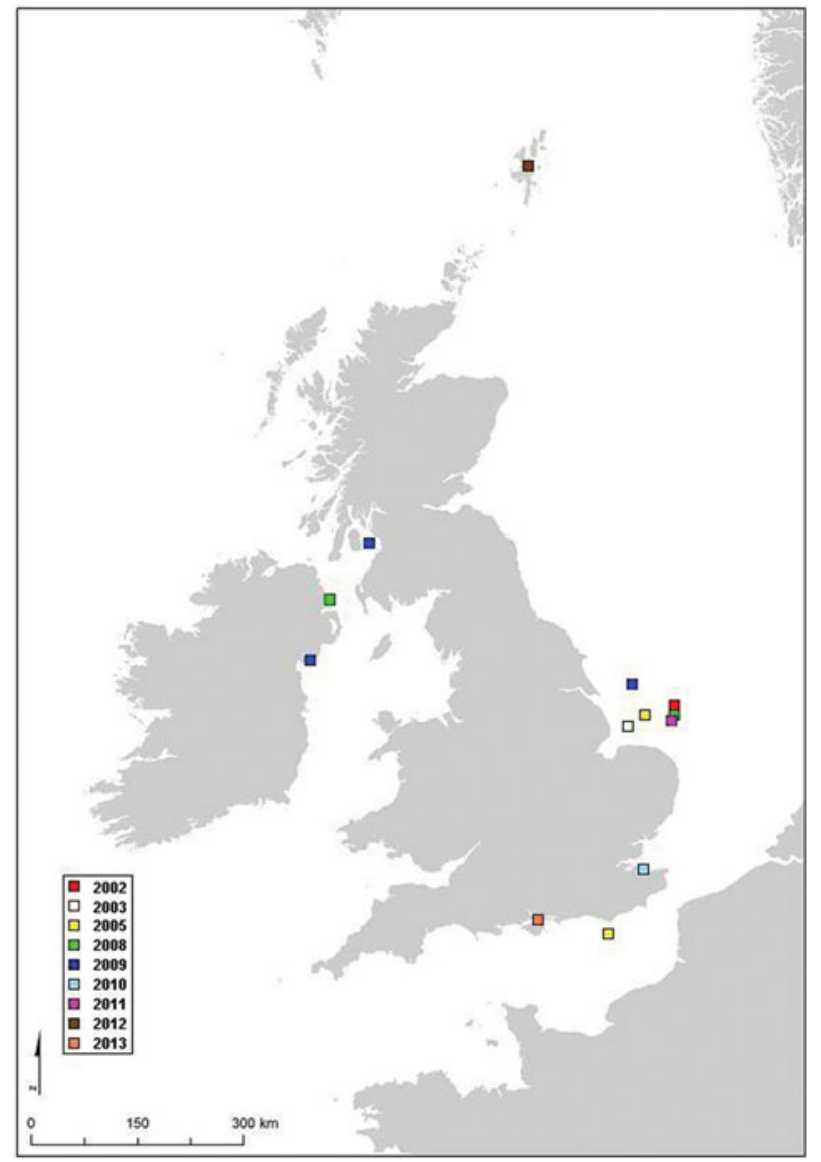

Fig. 5. Map showing locations of some confirmed specimens of Fenestrulina delicia. 


\section{CONCLUSION}

Escharoides bishopi appears to be genuinely rare so it is of no surprise that it has not been recorded from the UK before. Fenestrulina delicia on the other hand appears to be widespread and has been seriously overlooked. It is now known that this species has been present in European waters from 2002 though if more archival material is analysed this date could easily be pushed further back. The specimens and data held by British commercial laboratories in this case have given a new insight into the spatial and temporal distribution of this recently arrived species. Commercial laboratories engaged in marine faunal identification are an arguably overlooked resource of information for the advancement of taxonomic and distributional knowledge. Commercial sensitivities may be assumed or cited but this publication demonstrates a willingness to collaborate on matters of academic interest.

\section{ACKNDWLEDGEMENTS}

Many thanks to: the commercial clients Lafarge Tarmac Marine Ltd and Van Oord UK Ltd; Emma Delduca, David Alexander, Bianka Rasch and Angela De Burgh-Thomas of MESL and Ross Griffin and Jack Pitts formerly of MESL for assistance with the MESL archives, mapping, distributional data and client communication; Andy Mackie, Anna Holmes and Katie Mortimer-Jones of The National Museum of Wales in Cardiff for use of and assistance with the SEM facilities; Steve Jarvis of Marine Invertebrate Ecological Services, Carol Milner of APEM, Alison Bessell and Grant Rowe of Fugro EMU and Ruth Barnich of Thomson Unicomarine for the loan of specimens; John Hartley of Hartley Anderson Ltd for sample information; and Mary Spencer-Jones at the Natural History Museum, London for lodging specimens in the collection there and for permission to use the image of Fenestrulina malusii.

\section{REFERENCES}

Craig S.F. (1994) Intraspecific fusion in the encrusting bryozoan Fenestrulina sp. In Hayward P.J., Ryland J.S. and Taylor P.D. (eds) Biology and paleobiology of bryozoans. Fredensborg, Denmark: Olsen \& Olsen, pp. 51-54.

De Blauwe H. (2006) Bryozoa on shells from the Kwintenbank, Southern Bight of the North Sea (Belgium). Bulletin Van Het Koninklijk Belgisch Instituut Voor Natuurwetenschappen Biologie 76, 125-138

De Blauwe H. (2008) Fenestrulina delicia Winston, Hayward \& Craig 2000, een nieuw mosdiertje (Cheilostomata, Bryozoa) in Europa. De Strandvlo 28, 154-157.

De Blauwe H. (2009) Mosdiertjes van de Zuidelijke bocht van de Noordzee: Determinatiewerk voor België en Nederland. Oostende, The Netherlands: Vlaams Instituut voor de Zee (VLIZ), 445 pp.

De Blauwe H. (2012) Zandsuppleties afkomstig van de Buiten Ratel in maart 2012 op het strand te Knokke. De Strandvlo 32, 24-27.

De Blauwe H., Kind B., Kuhlenkamp R., Cuperus J., van der Weide B. and Kerckhof F. (2014) Recent observations of the introduced Fenestrulina delicia Winston, Hayward \& Craig, 2000 (Bryozoa) in Western Europe. In Rosso A., Wyse Jackson P.N. and Porter J. (eds) Bryozoan Studies 2013. Studi Trentini di Scienze Naturali 94, 45-51. [Museo delle Scienze, Trento.]

Hayward P.J. and Ryland J. (1998) Cheilostomatous Bryozoa. Part I. Aeteoidea-Cribrilinoidea. Synopses of the British Fauna (New Series) No. 10. 2nd edition. Shrewsbury: Field Studies Council.

and

Winston J.E., Hayward P.J. and Craig S.F. (2000) Marine bryozoans of the Northeast Coast of the United States: new and problem species. In Herrera Cubilla A. and Jackson J.B.C. (eds) Proceedings of the 11th International Bryozoology Associaton Conference. Balboa, Republic of Panama: Smithsonian Tropical Research Institute, pp. 412-420.

\section{Correspondence should be addressed to:}

B. Wasson

Marine Ecological Surveys Ltd

3 Palace Yard Mews, Bath, BA1 $2 \mathrm{NH}$

email: bryan.wasson@mesltd.co 